\title{
Effect of Rainfall on the Prevalence of Fascioliasis in Puerto Rico ${ }^{1}$
}

\author{
Lawrence S. Ritchie, Jorge Chiriboga, Delfín D. de León, P. A. \\ Gómez, and A. Velarde ${ }^{2}$
}

\begin{abstract}
Extraordinary numbers of Lymnaea cubensis snails were noted in the Dorado area of Puerto Rico in February 1971, coincident with heavy rainfall from October through December 1970. Fasciola hepatica occurred in snails at a modal rate of $4 \%$, assuring vast numbers of infected snails and metacercariae. A snail density determination was made for subsequent comparison, and six of 19 herds of cattle examined previously (1970) were reexamined to determine changes in occurrence of fascioliasis. By May 1971, most of the snails were decimated and had not reoccurred by September 1972. Frequency of Fasciola hepatica and egg counts doubled after the snail bloom, but returned to normal by mid-1972. The need for long term epidemiological research on fascioliasis in Puerto Rico is indicated.
\end{abstract}

\section{INTRODUCTION}

Remarkable numbers of Lymnaea cubensis snails were encountered throughout the Dorado area of Puerto Rico in February 1971, greatly in excess of cursory observations over two previous years. This episode was coincident with heavy rainfall during October, November, and December 1970, that was 2- to 3-fold in excess of a 20 year norm (19511970). Severe flood covered many pastures and frequent rains kept low spots of even a few square meters swampy. These were densely inhabited by $L$. cubensis, the predominant intermediate host of Fasciola hepatica in Puerto Rico. The rate of occurrence of this parasite in the snails assured vast numbers of positive specimens and emerging cercariae. That there would be an effect on the epidemiology of fascioliasis was conjectured, and 6 to 19 herds of cattle that had been examined late in 1970 were reexamined. Whatever the impact, its duration was for only a few months. A review of rainfall records for 1951 to 1970 revealed that only in 1956 was there rainfall comparable to that of 1970.

There is a precedent for the observations made in this study in the

${ }^{1}$ Manuscript submitted to Editorial Board April 21, 1977.

2 Former Director of Puerto Rico Nuclear Center; Senior Scientist, Center for Energy and Environment Research; formerly Scientist, Puerto Rico Nuclear Center; Fellow in Parasitology at the Puerto Rico Nuclear Center; Fellow in Parasitology at Puerto Rico Nurlear Center. Puerto Rico Nuclear Center is now Center for Energy and Environment Research, University of Puerto Rico. 
reports of Ollerenshaw and Rowlands ${ }^{3}$ and Ollerenshaw ${ }^{4}$. However, a correlation of rainfall, snail population densities, and occurrence of fascioliasis in Puerto Rico has not been reported, nor has it been reported for other tropical environs.

\section{PROCEDURE}

Thirty one snail colonies, ranging in size from about 100 to several hundred square feet, were selected on six farms for making snail counts. These were made at 8-week intervals from March 1971 through September 1972. On these occasions, snails were counted in eight circular quadrates $\left(17 \mathrm{in}^{2}\right)$ in each colony. An imprint was made on the mud with a metal tube, and snails were counted in situ without disturbing them. Circumstances were deemed unfavorable for collecting data suitable for mathematical, epidemiological formulas, and since they were for comparative purposes, select quadrates where the snails were most numerous were chosen. They were, however, well distributed throughout the colony.

Infections of Fasciola hepatica in Lymnaea cubensis were determined by crushing collections taken from colonies other than those used for snail population densities, Paramphistoma sp. infections occurred frequently and were excluded.

To determine if there has been any change in fascioliasis, the cattle on each of the six farms selected, were reexamined, They were among the herds reported by de León et al. (herds No. 1, 3, 5, 8, 14, 16). ${ }^{5}$ They had been examined prior to the blooms of snails and were reexamined from September through December 1971 and again near midyear 1972.

The procedures used in collecting and processing fecal specimens were those reported by de León et al. (1972). ${ }^{5}$ The microscopists were the same for the examinations in 1971 and 1972, and the skills of those serving in 1970 were judged comparable.

\section{RESULTS}

In March 1971, while a peak snail population prevailed, a total of 5,265 snails were counted in 248 quadrates in 31 colonies, a mean of 21.2 snails per quadrate (table 1). The total quadrates represented $4,216 \mathrm{in}^{2}$ for a mean density of more than one snail per in ${ }^{2}$. In May snails were found in only 11 of 27 colonies examined and the mean per

${ }^{3}$ Ollerenshaw, C. B., and Rowlands, W. T., 1959. A method of forecasting the incidence of fascioliasis in Anglesey, Vet. Med. 71: 591-8.

${ }^{4}$ Ollerenshaw, C. B., 1966. The approach to forecasting the incidence of fascioliasis over England and Wales, 1958-62, Agric. Meteorol., 3: 35-53.

${ }^{5}$ De León, D., Ritchie, L. S., and Chiriboga, J., 1972. Fascioliasis in dairy cattle in the Dorado area, J. Agri. Univ. P.R., 56(1): 88-92. 
quadrate was only 3.5. At this time most of the habitats were dry, excepting one farm where most of the snails were found. In August, only 5 to 29 colonies were found with a mean of 0.4 snails per quadrate, or about $2 \%$ of the original population density. Thereafter, through April 1972, the numbers did not exceed $13 \%$ of the original population. Moreover, they were limited to 8 of 24 habitats that were still available for observation; five habitats were destroyed when a pasture was plowed, and the identities of two others were lost.

TABLE 1. - Population trends for Lymnaea cubensis in the Dorado Area of Puerto Rico

\begin{tabular}{|c|c|c|c|c|c|}
\hline \multirow{2}{*}{ Month } & \multicolumn{2}{|c|}{ Snail colonies } & \multirow{2}{*}{$\begin{array}{c}\text { Total } \\
\text { quadrates }\end{array}$} & \multicolumn{2}{|c|}{ Snail population } \\
\hline & $\begin{array}{l}\text { Number } \\
\text { examined }\end{array}$ & $\begin{array}{l}\text { Number } \\
\text { with snails }\end{array}$ & & $\begin{array}{c}\text { Total } \\
\text { counted }\end{array}$ & $\begin{array}{l}\text { Mean/ } \\
\text { quadrate }\end{array}$ \\
\hline \multicolumn{6}{|l|}{1971} \\
\hline March & 31 & 31 & 248 & 5,265 & 21.2 \\
\hline May & 27 & 11 & 216 & 755 & 3.5 \\
\hline August & 29 & 5 & 232 & 102 & .4 \\
\hline Oct.-Nov. & 27 & 5 & 216 & 239 & 1.1 \\
\hline December & 24 & 7 & 192 & 228 & 1.2 \\
\hline \multicolumn{6}{|l|}{1972} \\
\hline January & 24 & 8 & 192 & 376 & 2.0 \\
\hline March & 24 & 8 & 192 & 518 & 2.7 \\
\hline April & 24 & 5 & 192 & 113 & .6 \\
\hline September & 23 & 5 & 184 & 236 & 1.3 \\
\hline
\end{tabular}

Infected snails occurred on all six farms, with infection rates of $4 \%$ for three and 26,17 , and $0.5 \%$ for the others. ${ }^{5}$

The occurrence of Fasciola hepatica increased considerably in the six herds selected for reexamination, the overall increase being from $47 \%$ to $85 \%$. Frequency of infection on two farms quadrupled from $18 \%$ and $24 \%$ in 1970 to $75 \%$ and $94 \%$, respectively, in 1971. On three farms where the figures were $33 \%, 51 \%$, and $51 \%$ in 1970 , they were $74 \%$, $78 \%$, and $81 \%$ in 1971 . For the 6 th farm, the original rate of $80 \%$ increased to $96 \%$. The numbers of Fasciola hepatica eggs in the fecal specimens in 1971 were in most cases more than double those of 1970 for the six farms (table 2).

Near midyear 1972, four of the six herds were again examined, and the occurrence of Fasciola hepatica and the egg counts approximated those of 1970, suggesting an early, spontaneous reduction of the parasite.

The rainfall data (table 3) showed 3-, 2-, and 1/2-fold increases for October, November, and December, respectively, as compared with the 20-year norm for 1951 to 1970. For September, precipitation was normal, slightly increased during June through August, and below normal 

JOURNAL OF AGRICULTURE OF UNIVERSITY OF PUERTO RICO

TABLE 2. - Findings on Fasciola hepatica for dairy herds in the Dorado Area

\begin{tabular}{|c|c|c|c|c|c|c|c|c|c|}
\hline \multirow{2}{*}{$\begin{array}{l}\text { Farm } \\
\text { No. }\end{array}$} & \multicolumn{3}{|c|}{ Cows examined } & \multicolumn{3}{|c|}{ Cows infected } & \multicolumn{3}{|c|}{ Mean egg counts } \\
\hline & 1970 & 71 & 72 & 70 & 71 & 72 & 70 & 71 & 72 \\
\hline & & No. & & $\%$ & $\%$ & $\%$ & $\%$ & $\%$ & $\%$ \\
\hline 1 & 70 & 74 & 70 & 51 & 78 & 51 & 6.4 & 8.9 & 3.6 \\
\hline 3 & 50 & 50 & 60 & 26 & 94 & 43 & 1.7 & 32.0 & 2.6 \\
\hline 5 & 59 & 70 & $\mathrm{nd}^{1}$ & 56 & 81 & - & 5.7 & 9.9 & - \\
\hline 8 & 54 & 74 & 75 & 33 & 74 & 33 & 2.2 & 6.9 & 2.0 \\
\hline 14 & 50 & 40 & 60 & 18 & 75 & 28 & 1.6 & 8.5 & 3.8 \\
\hline 16 & 75 & 143 & nd & 80 & 96 & - & 8.2 & 17.4 & - \\
\hline
\end{tabular}

1 Not done.

TABle 3. - Monthly rainfall for Dorado Area (inches)

\begin{tabular}{lrrrr}
\hline \multicolumn{1}{c}{ Month } & 1956 & 1965 & 1970 & Mean (1951-70) \\
\hline January & 15.06 & 1.55 & 6.11 & 5.1 \\
February & 7.87 & 1.27 & 2.51 & 3.2 \\
March & 10.09 & 3.25 & 1.13 & 3.1 \\
April & 3.59 & 2.28 & 1.52 & 4.6 \\
May & 15.09 & 21.12 & 5.90 & 7.0 \\
June & 9.11 & 7.38 & 8.71 & 5.9 \\
July & 7.35 & 7.95 & 9.08 & 7.5 \\
August & 7.96 & 8.46 & 10.56 & 7.6 \\
September & 5.52 & 6.06 & 5.01 & 5.6 \\
October & 12.60 & 5.99 & 17.07 & 5.1 \\
November & 8.27 & 9.92 & 13.81 & 7.0 \\
December & 10.39 & 9.05 & 18.04 & 7.3 \\
Total & 112.9 & 84.3 & 99.5 & 69.0 \\
\hline
\end{tabular}

TABLE 4. - Annual rainfall for the Dorado Area (1951-1970)

\begin{tabular}{rrrc}
\hline Year & Inches & Year & Inches \\
\hline 1951 & 65.5 & 1961 & 73.2 \\
1952 & 68.4 & 1962 & 59.3 \\
1953 & 59.6 & 1963 & 62.8 \\
1954 & 70.5 & 1964 & 49.1 \\
1955 & 68.2 & 1965 & 84.3 \\
1956 & 112.9 & 1966 & 70.1 \\
1957 & 58.9 & 1967 & 44.9 \\
1958 & 69.2 & 1968 & 66.5 \\
1959 & 62.2 & 1969 & 60.9 \\
1960 & 66.7 & 1970 & 99.5 \\
\hline
\end{tabular}

earlier in 1970. The total rainfall for the year was 99.5 inches as compared with the norm of 69.0 inches. From 1951 to 1970 there was only one other year (1956) with rainfall that matched that of 1970 (99.5 inches). Again the months of October through December were high, the total for 1956 being 112.9 inches (table 4). In 1965, precipitation was 
84.3 inches and variance from the norm was due to heavy rains in only one month (May).

\section{DISCUSSION}

The extraordinary population of Lymnaea cubensis snails was probably the result of 3 months of heavy rainfall which followed months of near-normal precipitation. This inference is supported by biological observations on this snail species, which showed that the egg to egg cycle may be as short as three weeks. This is undoubtedly a unique feature, allowing the snail to exploit brief intervals of heavy rainfall for propagation and increased transmission of Fasciola hepatica. Another related biological feature of $L$. cubensis is the occasional survival of a few snails for long periods of dryness. This has been demonstrated by Chiriboga et al. ${ }^{6}$ Although survival for a decade or longer without apparent propagation is incredible, this possibility must be given consideration. An alternate source of seed snails for multitudinous colonies over pastures might be the flushing and distributing of progenitors from permanent colonies by heavy flood waters.

More information must be obtained on snail population dynamics before control measures can be selected with confidence, and two distinct snail populations must be evaluated, those that persist because the habitats are wet most of the time, and those in habitats that are suitable for snails only periodically, i.e., only when rainfall is high. If such habitats must be repopulated by specimens scattered by floods from permanent habitats, then control of the snails in these during years of normal rainfall becomes doubly important. Their destruction. should minimize infections in cattle to such a point that an occasional dense snail population might be decimated naturally before transmission of infection to and from the snails could occur.

That the bloom of snails would account for an impact on the epidemiology of fascioliasis was anticipated, even though the time of snail survival was for only a few months. Snail infections on three farms of $4 \%$, and of $17 \%$ and $26 \%$ on two others must have accounted for great numbers of infected specimens and metacercariae. The data on six herds of cattle confirm this inference, revealing that the occurrence of infections and egg numbers were about doubled as noted in the last quarter of 1971. However, the impact was brief, as the status of fascioliasis by mid 1972 was essentially what it was in 1970. This finding agrees with previous observations that cattle are capable of spontaneous cure, whereas sheep retain infections longer. This suggests

${ }^{6}$ Chiriboga, J., Ritchie, L. S., and de León, D., 1975. On the cryptobiosis of Lymnaea cubensis, the snail vector of Fasciola hepatica in Puerto Rico, J. Agric. Univ. P.R. 59(3): 236-7. 
that infections in cattle in the Dorado area are maintained by continuous low-grade transmission from permanent colonies of snails, with greater intensities occurring occasionally.

There are numerous factors predicating transmission of fascioliasis, including: the closeness that grass is cropped, the location of snails in relation to main paths the cattle follow going to and from the pasture, the occurrence of snails in shaded places and favorite grazing areas, the frequency and duration of conspicuous water in the snail habitat, and the density of the vegetation. Information on all of these points is lacking in Puerto Rico.

Losses due to fascioliasis are so important that further effort should be devoted to the study of the epidemiology and control of fascioliasis in Puerto Rico.

\section{RESUMEN}

Cantidades enormes del caracol Lymnaea cubensis se encontraron en Dorado, Puerto Rico en el mes de febrero de 1971, después de una época de fuerte lluvia en 1970. La tasa media de caracoles infectados con F asciola hepatica fue de $4 \%$, indicando numerosos caracoles infectados y metacercarias. Se determinó el número de caracoles para una futura comparación, y 6 de los 19 rebaños examinados anteriormente (en 1970) fueron reexaminados para determinar cambios en la incidencia de fascioliasis. Para mayo de 1971 la mayoría de los caracoles había desaparecido y no regresaron hasta septiembre de 1972. La frecuencia de Fasciola hepatica y de huevos aumentó al doble después del brote de caracoles, pero ésta regresó a un nivel normal a mediados del 1972. Estos cambios subrayaron la necesidad de investigaciones epidemiológicas a largo plazo en Puerto Rico. 